HOLOCAUST ODYSSEYS 

SUSAN ZUCCOTTI

\section{Holocaust Odysseys}

THE JEWS OF SAINT-MARTIN-VÉSUBIE AND

THEIR FLIGHT THROUGH FRANCE AND ITALY

YALE UNIVERSITY PRESS NEW HAVEN \& LONDON 
Copyright (C) 2007 by Susan Zuccotti.

All rights reserved.

This book may not be reproduced, in whole or in part, including illustrations, in any form (beyond that copying permitted by Sections 107 and 108 of the U.S. Copyright Law and except by reviewers for the public press), without written permission from the publishers.

Set in FontShop Scala and Scala Sans type by Duke \& Company, Devon, Pennsylvania.

Printed in the United States of America by Vail-Ballou Press, Binghamton, New York.

Library of Congress Cataloging-in-Publication Data

Zuccotti, Susan.

Holocaust odysseys : the Jews of Saint-Martin-Vésubie and their flight through France and Italy / Susan Zuccotti.

p. $\mathrm{cm}$.

Includes bibliographical references and index.

ISBN 978-0-300-12294-7 (clothbound : alk. paper)

1. Jews-France-Saint-Martin-Vésubie—Biography. 2. Jewish children in the Holocaust—FranceSaint-Martin-Vésubie—Biography. 3. Holocaust, Jewish (1939-1945)—France—Personal narratives.

4. Holocaust, Jewish (1939-1945) - Italy-Personal narratives. 5. World War, 1939-1945-Deportations from France-Personal narratives. 6. Holocaust survivors-Biography. 7. Saint-Martin-Vésubie (France)-Biography. I. Title.

$$
\begin{aligned}
& \text { DS135.F89z83 } 2007 \\
& 940.53^{\prime} 1809224494-\mathrm{dc2} 2
\end{aligned}
$$

2007000431

A catalogue record for this book is available from the British Library.

The paper in this book meets the guidelines for permanence and durability of the Committee on Production Guidelines for Book Longevity of the Council on Library Resources.

$\begin{array}{llllllllll}10 & 9 & 8 & 7 & 6 & 5 & 4 & 3 & 2 & 1\end{array}$ 
To Nicholas, Emma, Sophie, and Robby 
